\title{
Productive and morphogenetic responses of buffel grass at different air temperatures and $\mathrm{CO}_{2}$ concentrations
}

\author{
Roberta Machado Santos ${ }^{1,3}$, Tadeu Vinhas Voltolini ${ }^{2}$, Francislene Angelotti ${ }^{2}$, Saulo de Tarso \\ Aidar $^{2}$, Agnaldo Rodrigues de Melo Chaves ${ }^{2}$
}

\author{
${ }^{1}$ Programa de Pós-graduação em Recursos Genéticos Vegetais, Universidade Federal de Feira de Santana - Feira de Santana, BA, Brasil. \\ ${ }^{2}$ Embrapa Semiárido, Petrolina, PE, Brasil. \\ ${ }^{3}$ Graduate fellow student by FACEPE.
}

\begin{abstract}
The objective of the present trial was to evaluate the productive and morphogenetic characteristics of buffel grass subjected to different air temperatures and $\mathrm{CO}_{2}$ concentrations. Three cultivars of buffel grass (Biloela, Aridus and West Australian) were compared. Cultivars were grown in growth chambers at three temperatures (day/night): 26/20, 29/23, and $32 / 26{ }^{\circ} \mathrm{C}$, combined with two concentrations of $\mathrm{CO}_{2}: 370$ and $550 \mu \mathrm{mol} \mathrm{mol}{ }^{-1}$. The experimental design was completely randomized, in a $3 \times 3 \times 2$ factorial arrangement with three replications. There were interactions between buffel grass cultivars and air temperatures on leaf elongation rate (LER), leaf appearance rate (LAR), leaf lifespan (LL) and senescence rate (SR), whereas cultivars $v s$. carbon dioxide concentration affected forage mass (FM), root mass (RM), shoot/root ratio, LL and SR. Leaf elongation rate and SR were higher as the air temperature was raised. Increasing air temperature also promoted an increase in LAR, except for West Australian. High $\mathrm{CO}_{2}$ concentration provided greater SR of plants, except for Biloela. Cultivar West Australian had higher FM in relation to Biloela and Aridus when the $\mathrm{CO}_{2}$ concentration was increased to $550 \mu \mathrm{mol} \mathrm{mol}^{-1}$. West Australian was the only cultivar that responded with more forage mass when it was exposed to higher carbon dioxide concentrations, whereas Aridus had depression in forage mass. The increase in air temperatures affects morphogenetic responses of buffel grass, accelerating its vegetative development without increasing forage mass. Elevated carbon dioxide concentration changes productive responses of buffel grass.
\end{abstract}

Key Words: carbon dioxide, Cenchrus ciliaris, climate change

\section{Introduction}

Human activities have been identified as major determinants of climate changes. Among these changes are the increase in air temperature and atmospheric $\mathrm{CO}_{2}$ concentration. According to IPCC (2007), the temperature of the Earth may increase from 2 to $6{ }^{\circ} \mathrm{C}$ throughout the present century, while the $\mathrm{CO}_{2}$ concentration can rise from the current $360 \mu \mathrm{mol} \mathrm{mol}^{-1}$ to $550 \mu \mathrm{mol} \mathrm{mol}^{-1}$.

Arid and semiarid regions, which represent large areas around the globe, may be quite vulnerable in terms of possible changes in climate, especially the agricultural and livestock systems, which are very important to those places (Barros, 2011). According to IPCC (2013), $\mathrm{CO}_{2}$ levels in 2011 were $391 \mu \mathrm{mol} \mathrm{mol}^{-1}$, exceeding the pre-industrial values by about $40 \%$.

In this region, as well as in other arid and semiarid regions worldwide, buffel grass (Cenchrus ciliaris L.) is

Received June 10, 2013 and accepted April 28, 2014.

Corresponding author: tadeu.voltolini@embrapa.br

http://dx.doi.org/10.1590/S1516-35982014000800002

Copyright $\odot 2014$ Sociedade Brasileira de Zootecnia. This is an Open Access article distributed under the terms of the Creative Commons Attribution Non-Commercial License, which permits unrestricted non-commercial use, distribution, and reproduction in any medium, provided the original work is properly cited. one of the most important grasses for livestock (Baig et al., 2005; Voltolini et al., 2010, 2011; Souza et al., 2013). A negative impact on buffel grass pastures may promote considerable social and economic losses. Information on physiological responses and quality of forage plants is important to foresee and mitigate the impacts of climate change and encourage the development of public policies (Santos et al., 2011).

The increase in temperature is noted as a factor that can elevate the biomass production of C4 plants (Zhu et al., 2008). In a classic study evaluating several tropical legumes and grasses in relation to temperature increase, Sweeney and Hopkinson (1975) concluded that Cenchrus ciliaris showed no depression in productive response with increase in temperature.

Regarding carbon dioxide concentration, it is not clear whether a rise in atmospheric $\mathrm{CO}_{2}$ partial pressure will also influence the productivity of the $\mathrm{C} 4$ grasslands. The reason for this uncertainty is that relatively few $\mathrm{CO}_{2}$ enrichment studies have focused on the response of $\mathrm{C} 4$ grasses compared with the large number of studies on $\mathrm{C} 3$ plants (Ghannoum et al., 2000).

Contrary to earlier hypotheses that the growth of $\mathrm{C} 4$ grasses would not change in high $\mathrm{CO}_{2}$, Wand et al. (1999) 
and Ghannoum et al. (2000) suggest that the growth responses of $\mathrm{C} 4$ plants to doubling the current $\mathrm{CO}_{2}$ ranges from $22 \%$ to $33 \%$. Thus, the objective of this study was to evaluate productive and morphogenetic characteristics of three buffel grass cultivars subjected to different air temperatures and $\mathrm{CO}_{2}$ concentrations.

\section{Material and Methods}

The experimental trial was carried out at Campo Experimental da Caatinga, Embrapa Semiarido - Petrolina/ $\mathrm{PE}$, at latitude $09^{\circ} 04^{\prime} 16,4^{\prime \prime S}$, longitude $40^{\circ} 19^{\prime} 5,37^{\prime \prime} \mathrm{W}$, elevation $379 \mathrm{~m}$. Two growth chambers (phytotron) measuring $3.10 \times 1.90 \times 2.50 \mathrm{~m}$ with controlled air $\mathrm{CO}_{2}$ concentration, air temperature, humidity (40-60\%) and light were used.

Three cultivars of buffel grass (Cenchrus ciliaris L.) - (Biloela, Aridus and West Australian), characterized by high (1-1.6 m), medium $(0.75-1.0 \mathrm{~m})$ and low height (up to $0.75 \mathrm{~m}$ ), respectively, were evaluated. The plants were grown in plastic pots with volume capacity of $16 \mathrm{~L}$ containing soil classified as Vertisol, collected from Campo Experimental de Bebedouro (latitude: 0909'S, longitude: $40^{\circ} 22^{\prime} \mathrm{W}$, elevation $365 \mathrm{~m}$ ), and organic fertilizer based on tanned sheep manure produced in Embrapa Semiarido, at the proportion of 2:1 (Table 1).

The experimental design was completely randomized, with three replicates, in a $3 \times 3 \times 2$ factorial arrangement (cultivars $\times$ air temperatures $\times \mathrm{CO}_{2}$ concentrations).

Ten days after sowing, plant thinning was performed, leaving five plants per pot. These plants were grown at three different temperatures (day/night): 26/20, 29/23 and $32 / 26^{\circ} \mathrm{C}$, combined with two $\mathrm{CO}_{2}$ concentrations (550 and $370 \mu \mathrm{mol} \mathrm{mol}{ }^{-1}$ ), and a photoperiod of 13 hours (fixed in $400 \mu \mathrm{mol} \mathrm{m} \mathrm{m}^{-2} \mathrm{~s}^{-1}$ of photosynthetic photon flux density continuously during the light period). The temperature treatments were defined based on the average air temperature of Petrolina region (Da Silva et al., 2005; Medeiros et al., $2005)$, with an increase of 3 and $6{ }^{\circ} \mathrm{C}$ from this temperature, 29 and $32{ }^{\circ} \mathrm{C}$, respectively.

The carbon dioxide concentration of $370 \mu \mathrm{mol} \mathrm{mol}^{-1}$ corresponds to the current concentration, and $550 \mu \mathrm{mol} \mathrm{mol}^{-1}$ represents possible future scenarios (IPCC, 2007). The $\mathrm{CO}_{2}$ concentration was monitored with the use of the SITRAD (4.8) software. The experiment was carried out in three phases, each one performed with the two $\mathrm{CO}_{2}$ concentrations (370 and $500 \mu \mathrm{mol} \mathrm{mol}{ }^{-1}$, one for each chamber) with the thermoperiods of $26 / 20,29 / 23$ and $32 / 26^{\circ} \mathrm{C}$ (day/night), respectively.

The experiment lasted 50 days for each treatment used, which was the time necessary for completing the plant physiological cycle. During the period, plants were watered daily, applying $300 \mathrm{~mL}$ of water per pot three times per week. The forage mass (FM) was evaluated at the end of the experimental period by cutting all five plants in each pot, at the ground level. Forage samples collected were predried in an oven at $55^{\circ} \mathrm{C}$ for 72 hours, ground to $1 \mathrm{~mm}$ and dried again at $105^{\circ} \mathrm{C}$ to obtain the dry weight.

All five plants were separated, three of which were full plants. The plant components (stem, leaves, inflorescence and dead material) were separated, constituting the samples of these components. After the removal plants from pots, roots were also collected, separated, washed to remove soil and left to dry in open air.

Thus, samples were composed of whole plant (shoot), (root, stem, leaves, inflorescence and dead material) for each replicate of their respective cultivar. All samples were weighed fresh and after drying in an oven at $55{ }^{\circ} \mathrm{C}$ for 72 hours. These data were used to estimate forage mass (FM), root mass (RM) and shoot/root (SR) ratio.

The plants were evaluated 15 days after sowing; however, to evaluate the morphogenetic characteristics, three tillers were marked in each pot, totaling 27 tillers for each treatment. The following measurements were recorded: tiller height, stem length, number of leaves, leaf blade length, leaf width and number of dead leaves.

The tiller height was estimated by measuring the tiller from the ground level up to the apex of the highest leaf. The stem length was measured from the highest point of the stem (ligule of highest expanded leaf) to the ground level. The number of leaves was obtained by direct counting expanded or expanding leaves per tiller. Leaf blade length was measured as the distance between the leaf apex and its ligule, considering expanded or expanding leaves. Leaf width was estimated by measuring the distance between

Table 1 - Results of chemical analysis of soil and organic fertilizer plus soil

\begin{tabular}{|c|c|c|c|c|c|c|c|c|c|}
\hline \multirow{2}{*}{ Samples } & $\mathrm{pH}\left(\mathrm{H}_{2} \mathrm{O}\right)$ & $\mathrm{P}^{1}$ & $\mathrm{~K}$ & $\mathrm{Ca}$ & $\mathrm{Mg}$ & $\mathrm{Al}$ & SB & $\mathrm{Fe}$ & $\mathrm{Zn}$ \\
\hline & \multicolumn{3}{|c|}{$\mathrm{mg} / \mathrm{dm}^{3}$} & \multicolumn{3}{|c|}{$\mathrm{cmolc} / \mathrm{dm}^{3}$} & \multicolumn{3}{|c|}{$\mathrm{mg} / \mathrm{dm}^{3}$} \\
\hline Soil & 4.8 & 4.8 & 0.21 & 2.0 & 1.0 & 0.1 & 3.23 & 22.6 & 3.8 \\
\hline
\end{tabular}

$\mathrm{SB}$ - sum of bases (Ca, Mg, $\mathrm{K}$ and $\mathrm{Na})$.

${ }^{1}$ Mehlich-1 extraction. 
the two edges of the leaves, while the number of dead leaves was estimated by direct counting leaves presenting more than $50 \%$ of their constitution as dead tissue. From these measurements, the morphogenetic and structural characteristics below were obtained:

Leaf lifespan (LL, days): estimated as the time between the appearance of the apex and the first sign of leaf senescence $(\mathrm{LL}=\mathrm{Tlv}-\mathrm{Tsn}$, in which Tlv $=$ time (days) for the appearance of leaf vertex; and Tsn = time (days) for the onset the first sign of senescence). Senescence rate ( $\mathrm{SR}, \mathrm{mm} /$ day): the loss of dead tissue (in $\mathrm{mm}$ ) of each tiller, calculated by dividing the value found by the number of days in the evaluation. Senescence rate (SR): total number of dead leaves/experimental growth days (50 days). Leaf elongation rate (LER, mm/leaf/day): calculated as the difference between initial and final leaf lengths; the leaf blade was measured up to its full expansion, i.e., until the appearance of the ligule (LER $=\Sigma$ ILleaves - FLleaves/D, in which $\Sigma=$ total sum of leaves; ILleaves = initial length of leaves; FLleaves $=$ final length of leaves; and D = time (experimental period, in days)). Leaf appearance rate (LAR, leaf/tiller/day): obtained by dividing the number of emerging leaves on marked tillers by the number of days involved (LAR $=$ total emerged leaves per tiller/ experimental growth days).

Statistical analyses were performed using the Assistat (2008) software version 7.5 beta, applying variance analysis and Tukey's test, considering as significant effect probability values lower than $5 \%(\mathrm{P}<0.05)$.

\section{Results and Discussion}

Forage mass (FM), root mass (RM), shoot/root ratio (SR ratio), life lifespan (LL), leaf elongation rate (LER), leaf appearance rate (LAR) and senescence rate (SR) were influenced by air temperatures. Cultivars affected LER, LAR, and SR, whereas the concentration of $\mathrm{CO}_{2}$ influenced $\mathrm{SR}$ ratio and SR (Table 2). There were interactions between buffel grass cultivars and air temperatures on LER, LAR, LL, and SR, whereas cultivars vs. carbon dioxide concentration affected FM, RM, SR ratio, LL, and SR (Table 2).

The FM was increased under $29 / 23$ and $32 / 26{ }^{\circ} \mathrm{C}$ in comparison with $26 / 20^{\circ} \mathrm{C}$. At $29 / 23$ and $32 / 26^{\circ} \mathrm{C}$ FM were similar (Table 3). According to Fernández et al. (2014), C4 plants have higher photosynthetic and metabolic rates at high temperatures, promoting more biomass.

Lower RM was found at $32 / 26{ }^{\circ} \mathrm{C}$, suggesting that the intermediate temperature $\left(29 / 23{ }^{\circ} \mathrm{C}\right)$ was the optimum point for root growth. Possibly, at $32 / 26^{\circ} \mathrm{C}$ plants presented high tissue synthesis rates (LAR, LER and SR) and the photoassimilates can be primarily directed to shoot in relation to root, promoting lower RM values. The lower SR ratio at $26 / 20{ }^{\circ} \mathrm{C}$ can be justified by the higher response of FM at $29 / 23$ and $32 / 26{ }^{\circ} \mathrm{C}$, promoted by higher tissue synthesis.

The FM, RM and SR ratio were not affected by the interaction between cultivars and air temperatures, indicating that all three buffel grass cultivars could be used in temperatures up to $32 / 26{ }^{\circ} \mathrm{C}$.

Santos et al. (2013), who evaluated germinative responses of Biloela, Aridus and West Australian, suggested 25.5 to $31.5^{\circ} \mathrm{C}$ as the optimum range for buffel grass seed germination, and reported that seeds of these cultivars presented tolerance to the temperature of $40{ }^{\circ} \mathrm{C}$.

At $26 / 20{ }^{\circ} \mathrm{C}$ (day/night), Biloela had shorter LL in comparison with Aridus, whereas West Australian showed lower LAR than the others. Leaf elongation rates were similar for all three buffel grass cultivars evaluated. At a high temperature combination $\left(32 / 26^{\circ} \mathrm{C}\right)$, West Australian had lower LER, LAR and LL in comparison with Aridus and Biloela. At this same temperature $\left(32 / 26^{\circ} \mathrm{C}\right)$, the lowest SR was found for Biloela (Table 4).

According to Newman et al. (2001), FM for C4 plants is increased when they are exposed to a temperature above the standard. In their study, they found 11 to $26 \%$ more FM increasing the air temperature by $4.5^{\circ} \mathrm{C}$ above the standard

Table 2 - P-values of main effects (cultivar, temperature and $\mathrm{CO}_{2}$ concentration) and interactions between buffel grass cultivars (C) and air temperatures $(\mathrm{T})$

\begin{tabular}{|c|c|c|c|c|c|c|c|}
\hline \multirow{2}{*}{ Effect } & \multicolumn{6}{|c|}{ Characteristic } & \multirow[b]{2}{*}{ SR } \\
\hline & FM & RM & SR ratio & LER & LAR & LL & \\
\hline $\mathrm{C}$ & $0.1553 \mathrm{~ns}$ & $0.0874 \mathrm{~ns}$ & $0.1203 \mathrm{~ns}$ & $<0.001 * *$ & $<0.001 * *$ & $0.0576 \mathrm{~ns}$ & $<0.001 * *$ \\
\hline $\mathrm{T}$ & $<0.001 * *$ & $<0.001 * *$ & $<0.001 * *$ & $<0.001 * *$ & $0.001 * *$ & $0.001 * *$ & $<0.001 * *$ \\
\hline $\mathrm{CO}_{2}$ & $0.245 \mathrm{~ns}$ & $>0.050 \mathrm{~ns}$ & $<0.001 * *$ & $>0.050 \mathrm{~ns}$ & $>0.050 \mathrm{~ns}$ & $0.1633 \mathrm{~ns}$ & $0.0262 *$ \\
\hline $\mathrm{C} \times \mathrm{T}$ & $>0.05 \mathrm{~ns}$ & $0.1329 \mathrm{~ns}$ & $0.2879 \mathrm{~ns}$ & $<0.001 * *$ & $0.0026 * *$ & $0.0021 * *$ & $<0.001 * *$ \\
\hline $\mathrm{C} \times \mathrm{CO}_{2}$ & $0.028^{*}$ & $0.002 * *$ & $0.0297^{*}$ & $0.0679 \mathrm{~ns}$ & $0.1339 \mathrm{~ns}$ & $<0.001 * *$ & $0.0055^{* *}$ \\
\hline
\end{tabular}

FM - forage mass (g of DM/pot); RM - root mass (g of DM/pot); SR ratio - shoot/root ratio; LER - leaf elongation rate (mm day ${ }^{-1}$ ); LAR - leaf appearance rate (leaf day ${ }^{-1}$ );

LL - leaf lifespan (days); SR - senescence rate $\left(\mathrm{mm} \mathrm{day}^{-1}\right)$.

$\mathrm{C}$ - cultivar; T - temperature; $\mathrm{CO} 2$ - concentration of $\mathrm{CO}_{2} ; \mathrm{C} \times \mathrm{T}$ - interaction between cultivar and temperature; $\mathrm{C} \times \mathrm{CO}_{2}-$ interaction between cultivar and concentration of $\mathrm{CO}_{2}$. 
temperature. In the present research, the obtained results were different because FM was not increased when the air temperature was raised from 3 to $6{ }^{\circ} \mathrm{C}$. However, this may have occurred because this variable was measured at the end of the growth cycle; thus lost senescent leaves during growth were not computed. On the other hand, the high temperature values applied in the present research may have not promoted more FM, probably due to the high tissue turnover which may have exerted greater energy expenditure by plants, thus lowering their FM accumulation.

On the other hand, the results found in present study are in accordance with those reported by Sweeney and Hopkinson (1975), who evaluated 19 tropical and subtropical grasses and legumes, including Cenchrus ciliaris

Table 3 - Forage mass (FM), root mass (RM) and shoot/root ratio (SR ratio) of buffel grass cultivars (Biloela, Aridus and West Australian) subjected to three air temperature combinations

\begin{tabular}{lcccc}
\hline \multirow{2}{*}{ Characteristic } & \multicolumn{3}{c}{ Air temperature (day/night) } & \multirow{2}{*}{$\mathrm{CV}(\%)$} \\
\cline { 2 - 4 } & $26 / 20{ }^{\circ} \mathrm{C}$ & $29 / 23^{\circ} \mathrm{C}$ & $32 / 26{ }^{\circ} \mathrm{C}$ & \\
\hline $\mathrm{FM}$, g of DM/pot & $5.92 \mathrm{~b}$ & $15.31 \mathrm{a}$ & $16.00 \mathrm{a}$ & 40.00 \\
$\mathrm{RM}$, g of DM/pot & $4.67 \mathrm{c}$ & $9.30 \mathrm{a}$ & $7.16 \mathrm{~b}$ & 24.90 \\
$\mathrm{SR}$ ratio & $1.03 \mathrm{~b}$ & $1.54 \mathrm{a}$ & $1.53 \mathrm{a}$ & 27.30 \\
\hline
\end{tabular}

Means followed by same letter in the rows did not differ statistically by Tukey's test, considering $5 \%$ of probability $(\mathrm{P}<0.05)$

$\mathrm{CV}$ - coefficient of variation.

Table 4 - Leaf elongation rate, leaf appearance rate, leaf lifespan and senescence rate of buffel grass cultivars in three combinations (day/night) of air temperature

\begin{tabular}{|c|c|c|c|}
\hline \multirow{2}{*}{ Cultivar } & \multicolumn{3}{|c|}{ Air temperature (day/night) } \\
\hline & $26 / 20^{\circ} \mathrm{C}$ & $29 / 23{ }^{\circ} \mathrm{C}$ & $32 / 26^{\circ} \mathrm{C}$ \\
\hline & \multicolumn{3}{|c|}{ Leaf elongation rate $\left(\mathrm{mm}\right.$ day $\left.^{-1}\right)$} \\
\hline Aridus & $44.16 \mathrm{aC}$ & $71.58 \mathrm{aB}$ & $82.06 \mathrm{aA}$ \\
\hline Biloela & $37.78 \mathrm{aC}$ & $45.71 \mathrm{cB}$ & $77.74 \mathrm{aA}$ \\
\hline West Australian & $37.43 \mathrm{aC}$ & $53.46 \mathrm{bB}$ & $63.37 \mathrm{bA}$ \\
\hline \multirow[t]{2}{*}{$\mathrm{CV}, \%$} & 9.62 & & \\
\hline & \multicolumn{3}{|c|}{ Leaf appearance rate ( leaf day ${ }^{-1}$ ) } \\
\hline Aridus & $0.21 \mathrm{aB}$ & $0.22 \mathrm{aB}$ & $0.25 \mathrm{aA}$ \\
\hline Biloela & $0.20 \mathrm{aAB}$ & $0.18 \mathrm{bB}$ & $0.21 \mathrm{bA}$ \\
\hline West Australian & $0.15 \mathrm{bA}$ & $0.16 \mathrm{cA}$ & $0.16 \mathrm{cA}$ \\
\hline \multirow[t]{2}{*}{$\mathrm{CV}, \%$} & 5.78 & & \\
\hline & \multicolumn{3}{|c|}{ Leaf lifespan (days) } \\
\hline Aridus & $15.59 \mathrm{aA}$ & $13.98 \mathrm{bB}$ & $12.90 \mathrm{aB}$ \\
\hline Biloela & $14.23 \mathrm{bB}$ & $15.38 \mathrm{aA}$ & $12.87 \mathrm{aC}$ \\
\hline West Australian & $15.63 \mathrm{aA}$ & $15.37 \mathrm{aA}$ & $13.12 \mathrm{aB}$ \\
\hline \multirow[t]{2}{*}{$\mathrm{CV}, \%$} & 5.32 & & \\
\hline & \multicolumn{3}{|c|}{ Senescence rate $\left(\mathrm{mm} \mathrm{day}^{-1}\right)$} \\
\hline Aridus & $9.36 \mathrm{bB}$ & $16.78 \mathrm{bB}$ & $57.51 \mathrm{aA}$ \\
\hline Biloela & $25.31 \mathrm{aB}$ & $34.12 \mathrm{aAB}$ & $41.06 \mathrm{bA}$ \\
\hline West Australian & $13.31 \mathrm{bC}$ & $34.64 \mathrm{aB}$ & $64.03 \mathrm{aA}$ \\
\hline $\mathrm{CV}, \%$ & 19.53 & & \\
\hline
\end{tabular}

Means followed by same letter (lowercase for columns and uppercase for rows) did not differ statistically by Tukey's test, considering $5 \%$ of probability $(\mathrm{P}<0.05)$. $\mathrm{CV}$ - coefficient of variation. at eight combinations of day/night temperatures rising in $3{ }^{\circ} \mathrm{C}$ steps from $15 / 10$ to $36 / 31{ }^{\circ} \mathrm{C}$, and reported no depression in growth rate for Cenchrus ciliaris when it was exposed to a high temperature, indicating that this forage plant could tolerate elevated temperatures without decreasing its production.

The increase in air temperature promoted significant differences in the the morphogenetic characteristics of buffel grass. The combination of temperatures tested (26/20, 29/23 and $32 / 26{ }^{\circ} \mathrm{C}$ - day/night) probably provided changes in biosynthesis rates, accelerating the phenological development of plants, which is in line with the reports described by Fageria et al. (2006).

On the other hand, a possible stimulation for biomass synthesis at daily temperature $\left(32 / 26^{\circ} \mathrm{C}\right.$ combination $)$ could have been annulled due to the higher night temperature, which might increase the intake of photoassimilates by respiration. Thus, new combinations of temperatures can be tested, using the minimum and maximum temperatures of the region as a reference index and thus applying new increments of temperature.

The increase in LER, LAR and SR and the decrease in LL represent acceleration in the phenological development of plants, with high vegetative tissue turnovers. Thus, despite the stimulation to increase forage mass by LER and LAR, there were higher losses of forage mass due to higher SR and lower LL, which suggests a physiological steady state of plants, in which there is adjustment in turnover rates of vegetative tissues. Consequently, the life cycle of these buffel grass cultivars is expected to reduce when air temperature is increased.

The acceleration in the phenological cycle of buffel grass rising air temperature may cause a considerable impact on pasture-based production systems, affecting mainly the grazing management, because the plants will have a faster development, rapidly reducing their nutritional value and thus reducing the time for grazing, which can reduce the efficiency of use of the produced forage. This fact will imply the need to establish new grazing management strategies for the buffel grass pastures.

West Australian presented approximately 15 to $25 \%$ lower FM in comparison with Aridus and Biloela, respectively, when it was exposed to $370 \mu \mathrm{mol} \mathrm{mol}{ }^{-1}$ of $\mathrm{CO}_{2}$. On the other hand, at $550 \mu \mathrm{mol} \mathrm{mol}{ }^{-1}$ of carbon dioxide concentration, West Australian and Biloela had similar FM and RM, but Aridus presented lower FM than with $370 \mu \mathrm{mol} \mathrm{mol} \mathrm{m}^{-1}$ (Table 4).

According to Ghannoum et al. (2000), the growth stimulation of $\mathrm{C} 4$ plants to a doubling of the current $\mathrm{CO}_{2}$ ranges from 22 to $33 \%$. In addition, Bhatt et al. (2007) 
reported that high carbon dioxide $(600 \mathrm{ppm})$ in a long-term exposure (120 days) promoted greater FM in Cenchrus ciliaris. The results found in present study, especially for West Australian, are in accordance with those reported by Ghannoum et al. (2000) and Bhatt et al. (2007).

Rudmann et al. (2001) evaluated the influence of high $\mathrm{CO}_{2}$ partial pressure on nitrogen use efficiency of the $\mathrm{C} 4$ grasses Panicum coloratum and Cenchrus ciliaris and reported that Cenchrus ciliaris had a consistently higher dry matter than Panicum coloratum, showing that buffel grass has a great capacity to produce more forage in a $\mathrm{CO}_{2}$-enriched atmosphere. Besides, dry mass partitioning varied between species and on average Cenchrus ciliaris allocated more dry matter to the stem plus sheath (42\%) than did Panicum coloratum (27\%). These studies support the results obtained in the present research, except for Aridus, whose productive responses of Cenchrus ciliaris could be increased or not impaired in an elevated $\mathrm{CO}_{2}$ atmosphere.

The increase in $\mathrm{CO}_{2}$ concentration ( 370 to $550 \mu \mathrm{mol} \mathrm{mol}^{-1}$ ) decreased FM for Aridus but provided significantly greater FM for West Australian. Similar SR ratios were found for Biloela and Aridus at 370 and $550 \mu \mathrm{mol} \mathrm{mol}^{-1}$ of $\mathrm{CO}_{2}$. In addition, West Australian presented higher SR ratio at 550 than $370 \mu \mathrm{mol} \mathrm{mol}^{-1}$ of $\mathrm{CO}_{2}$ (Table 5).

In the present research, Cenchrus ciliaris allocated $40 \%$ more for shoot than for root. Similar results were observed by Rudmann et al. (2001), who obtained higher shoot length at elevated $\mathrm{CO}_{2}$ and moderate $\mathrm{N}$ supply.

The absence of elevated $\mathrm{CO}_{2}$ concentration effects for FM, RM and SR ratio for Biloela is evidence that the plant has a $\mathrm{C} 4$ photosynthetic cycle. The photosynthetic

Table 5 - Interactions between buffel grass cultivars and carbon dioxide concentration $\left(\mathrm{CO}_{2}\right)$ for forage mass, root mass and shoot/root ratio

\begin{tabular}{ccc}
\hline \multirow{2}{*}{ Cultivar } & \multicolumn{2}{c}{$\mathrm{CO}_{2}\left(\mu \mathrm{mol} \mathrm{mol}^{-1}\right)$} \\
\cline { 2 - 3 } & 370 & 550 \\
\hline
\end{tabular}

Forage mass ( $\mathrm{g}$ of DM/pot) - CV $(\%)=40.26$

$\begin{array}{lll}\text { Aridus } & 5.05 \mathrm{aA} & 4.86 \mathrm{bA} \\ \text { Biloela } & 5.40 \mathrm{aA} & 5.90 \mathrm{abA} \\ \text { West Australian } & 3.44 \mathrm{bB} & 6.33 \mathrm{aA}\end{array}$

Root mass ( $\mathrm{g}$ of DM/pot) - CV $(\%)=24.90$

$\begin{array}{lcc}\text { Aridus } & 1.54 \mathrm{aA} & 1.24 \mathrm{aA} \\ \text { Biloela } & 1.24 \mathrm{aA} & 1.48 \mathrm{aA} \\ \text { West Australian } & 1.54 \mathrm{aA} & 1.82 \mathrm{aA} \\ & \text { Shoot/root ratio }-\mathrm{CV}(\%)=27.30 & \\ & 3.29 \mathrm{abA} & 3.80 \mathrm{aA} \\ \text { Aridus } & 4.30 \mathrm{aA} & 4.66 \mathrm{aA} \\ \text { Biloela } & 2.44 \mathrm{bB} & 3.73 \mathrm{aA} \\ \text { West Australian } & \end{array}$

Means followed by same letter (lowercase for columns and uppercase for rows) did not differ statistically by Tukey's test, considering $5 \%$ of probability $(\mathrm{P}<0.05)$. $\mathrm{CV}$ - coefficient of variation. assimilation for $\mathrm{C} 4$ plants is stimulated until $300 \mu \mathrm{mol}$ mol $^{-1}$ of atmospheric $\mathrm{CO}_{2}$ concentration, approximately, which means that the compensation point of $\mathrm{CO}_{2}$ occurs between 200 and $300 \mu \mathrm{mol} \mathrm{mol}^{-1}$ (Sage and Pearcy, 2000). This occurs because the decarboxilation process of organic acids in bundle-sheath cells results in an increase of approximately $1,000 \mathrm{ppm} \mathrm{CO}_{2}$, characterizing $\mathrm{C} 4$ metabolism that concentrates $\mathrm{CO}_{2}$ (Schulze et al., 2005). Thus, $550 \mathrm{ppm}\left(\mathrm{CO}_{2}\right.$ concentration applied in this study) is lower than the $\mathrm{CO}_{2}$ level that can be accumulated in bundle sheath cells under atmospheric $\mathrm{CO}_{2}$ concentration (Schulze et al., 2005). Therefore, the level of irradiance takes a decisive role for the modulation of photosynthetic assimilation of $\mathrm{C} 4$ plants.

However, in this study, although the irradiance $(400 \mu \mathrm{mol}$ photons $\mathrm{m}^{-2} \mathrm{~s}^{-1}$ ) was applied from a static source and by a constant way during the light period, it may have been a limiting factor to productive responses considering the highest temperature values applied. Different plant architectures can also interact differentially with nonsaturating irradiance, contributing to differences in light absorption between cultivars.

In the case of West Australian, exclusively, the increase in FM was observed with high $\mathrm{CO}_{2}$ concentration, corroborating Ghannoum et al. (1997) and Ghannoum and Conroy (1998). Ghannoum et al. (2000) suggest that increasing $\mathrm{CO}_{2}$ can benefit the growth of $\mathrm{C} 4$ plants by: 1) stimulating $\mathrm{CO}_{2}$ assimilation by increasing the partial pressure of intercellular spaces; 2) improving the water ratios of the shoots due to decreased transpiration, and consequently, increased leaf temperature; or 3) changes in daily patterns of $\mathrm{CO}_{2}$ fixation.

The elevated $\mathrm{CO}_{2}$ did not affect the productive characteristics of Biloela, decreased Aridus FM and increased FM for West Australian. These results indicate that in the current climate scenario, Biloela and Aridus are more productive than West Australian, but in the future climate scenario, considering the increase in carbon dioxide, West Australian may present similar productive performance compared with Biloela, and superior to that of Aridus.

Furthermore, other studies should be conducted addressing this issue to generate more information on the responses of forage plants, considering the prediction of future climate scenarios, aiming to strengthen strategies to reduce the impacts on the dry areas, like the Brazilian semiarid. These studies need to include the impacts of water stress in association with rising air temperature and carbon dioxide concentration, besides greater values of photosynthetic active radiation.

R. Bras. Zootec., 43(8):404-409, 2014 


\section{Conclusions}

The increase in day and night air temperatures affects the morphogenetic characteristics of buffel grass, accelerating its vegetative development without increasing its forage mass. Elevated carbon dioxide concentration changes productive responses of buffel grass.

\section{References}

ASSISTAT - Assistência estatística (2008). Download: version 7.5 beta. 2008. Available at: <http://www.assistat.com>. Accessed on: Nov. 18, 2012

Baig, M. J.; Anand, A.; Mandal, P. K. and Bhatt, R. K. 2005. Irradiance influences contents of photosynthetic pigments and proteins in tropical grasses and legumes. Photosynthetica 43:47-53.

Barros, J. D. S. 2011. Mudanças climáticas, degradação ambiental e desertificação do semiárido. Polêmica 10:476-483.

Bhatt, R. K.; Baig, M. J. and Tiwati, H. S. 2007. Growth, biomass production, and assimilatory characters in Cenchrus ciliaris L. under elevated $\mathrm{CO}_{2}$ condition. Photosynthetica 45:296-298.

Da Silva, B. B.; Lopes, G. M. and De Azevedo, P. V. 2005. Balanço de radiação em áreas irrigadas utilizando imagens landsat 5-TM. Revista Brasileira de Meteorologia 20:243-252.

Fageria, N. K.; Baligar, V. C. and Clark, R. B. 2006. Physiology of crop production. The Haworth Press, New York.

Fernández, G.; Teixeira, M. and Altesor, A. 2014. The small scale spatial pattern of $\mathrm{C} 3$ and $\mathrm{C} 4$ grasses depends on shrub distribution. Austral Ecology. doi: 10.1111/aec.12113.

Ghannoum, O. and Conroy, J. P. 1998. Nitrogen deficiency precludes a growth response to $\mathrm{CO}_{2}$ enrichment in $\mathrm{C} 3$ and $\mathrm{C} 4$ Panicum grasses. Australian Journal of Plant Physiology 25:627-636.

Ghannoum, O.; Von Caemmerer, S.; Barlow, E. W. R. and Conroy, J. P. 1997. The effect of $\mathrm{CO}_{2}$ enrichment and irradiance on the growth, morphology and gas exchange of a C3 (Panicum laxum) and a C4 (Panicum antidotale) grass. Australian Journal of Plant Physiology 24:227-237.

Ghannoum, O.; Von Caemmerer, S.; Ziska, L. and Conroy, J. P. 2000. The growth response of $\mathrm{C} 4$ plants to rising atmospheric $\mathrm{CO}_{2}$ partial pressure: a reassessment. Plant, Cell and Environment 23:931-942.

IPCC - Intergovernmental Panel on Climate Change. 2007. Summary for policymakers. 18p. In: Climate change 2007: The physical science basis. Contribution of Working Group I to the Fourth Assessment Report of the Intergovernmental Panel on Climate Change. IPCC, Genebra, Suiça.

IPCC - Intergovernmental Panel on Climate Change. 2013. Summary for policymakers. 33p. In: Climate change 2013: The physical science basis. Contribution of Working Group I to the Fifth Assessment Report of the Intergovernmental Panel on Climate Change. Stoker, T. F.; Qin, D.; Plattner, G-K.; Tignor, M.; Allen, S. K.; Boschung, J.; Nauels, A.; Xia, Y.; Bex, V. and Midgley, P. M., eds. Cambridge University Press, Cambridge, UK; New York, NY, USA.

Medeiros, S. S.; Cecilio, R. A.; Melo Junior, J. C. F. and Silva Junior, J. L. C. 2005. Estimativa e espacialização das temperaturas do ar mínimas, médias e máximas na Região Nordeste do Brasil. Revista Brasileira Engenharia Agrícola Ambiental 9:247-255.

Newman, Y. C.; Sollenberger, L. E.; Boote, K. J.; Allen Jr, L. H. and Littell, R. C. 2001. Carbon dioxide and temperature effects on forage dry matter production. Crop Science 41:399-406.

Rudmann, S. G.; Milham, P. J. and Conroy, J. P. 2001. Influence of high $\mathrm{CO}_{2}$ partial pressure on nitrogen use efficiency of the $\mathrm{C} 4$ Grasses Panicum coloratum and Cenchrus ciliaris. Annals of Botany 88:571-577.

Sage, R. F. and Pearcy, R. W. 2000. The physiological ecology of photosynthesis. p.497-532. In: Photosynthesis: Physiology and metabolism. Leegood, R. C.; Sharkey, T. D. and Von Caemmerer, S., eds. Kluwer Academic Publishers, The Netherlands.

Santos, P. M.; Voltolini, T. V.; Cavalcante, A. C. R.; Pezzopane, J. R. M.; Moura, M. S. B.; Silva, T. G. F.; Bettiol, G. M. and Cruz, P. G. 2011. Mudanças climáticas globais e a pecuária: Cenários futuros para o Semiárido brasileiro. Revista Brasileira de Geografia Física 4:1176-1196.

Santos, R. M.; Voltolini, T. V.; Angelotti, F. and Dantas, B. F. 2013. Germinação de sementes de capim-bufel em diferentes temperaturas. Pangeia Científica 1:11-17.

Schulze, E. D.; Beck, E. and Müller-Hphenstein, K. 2005. Plant ecology. Springer-Verlag, Berlin.

Souza, R.A.; Voltolini, T. V.; Araújo, G. G. L.; Pereira, L. G. R.; Moraes, S. A.; Mistura, C.; Belem, K. V. J. and Moreno, G. M. B. 2013. Consumo, digestibilidade aparente de nutrientes e balanços de nitrogênio e hídrico de ovinos alimentados com silagens de cultivares de capim-búfel. Arquivo Brasileiro de Medicina Veterinária e Zootecnia 65:526-536.

Sweeney, F. and Hopkinson, J. M. 1975. Vegetative growth of nineteen tropical and sub-tropical pasture grasses and legumes in relation to temperature. Tropical Grasslands 9:209-217.

Voltolini, T. V.; Araújo, G. G. L. and Moraes, S. A. 2010. Urea levels in multiple supplement for sheep grazing on buffel grass. Acta Scientiarum - Animal Sciences 32:461-465.

Voltolini, T. V.; Moraes, S. A.; Araújo, G. G. L. and Pereira, L. G. R. 2011. Concentrate levels for lambs grazing on buffel grass. Revista Ciência Agronômica 42:216-222.

Wand, S.; Midgley, G. and Musi, C. 1999. Physiological and growth responses of two African species, Acacia karoo and Themeda triandra, to combined increases in $\mathrm{CO}_{2}$ and UV-b radiation. Physiologia Plantarum 98:882-890.

Zhu, X.; Long, S. P. and Ort, D. R. 2008. What is the maximum efficiency with which photosynthesis can convert solar energy into biomass? Current Opinion in Biotechnology 19:153-159. 